\title{
7 \\ Reflections on a White Discipline
}

\author{
Laura Pulido
}

2002 The Professional Geographer 54(1), 42-9. ${ }^{1}$

\section{Introduction}

Several years ago I shifted my research focus from environmental racism/justice to questions of race, social movements, and political activism. Aside from the fact that these were deep passions, I was also driven by other factors. For one, I felt somewhat like a "poster child" when it came to people of color and environmental issues. Though confident that I was invited to speak frequently on these issues because of genuine interest in an alternative viewpoint, I was uncomfortable with often being the only person of color at such events. Second, and more important for this discussion, was my frustration with the absence of a substantive dialogue on race within the environmental racism/justice literature. This observation is not an indictment of geographers working in the field, but rather reflects some fundamental problems with the discipline itself. In particular, critical work on race remains relatively contained within urban and social geography, thus precluding a disciplinary conversation on the subject of race, with significant consequences for geography as a whole.

The confinement of the study of race to limited parts of geography has presented a real problem to me, as my academic life has been a continual struggle to integrate my anti-racist politics and participation in ethnic studies with geography. While aware of the importance of structural conditions, I have experienced this disjuncture as largely personal. Inspired by recent autobiographical work by geographers (Moss, 2000; Liverman, 1999), however, I have begun to rethink my personal history and concerns as indicative of larger disciplinary problems. As such,

${ }^{1}$ This text is based on the original manuscript before it was copyedited by The Professional Geographer. It is reprinted with permission from Laura Pulido and Wiley-Blackwell Publishing Ltd. 
my academic history is both an embodiment of the relationship between geography and race, as well as a product of engagement with a white discipline.

Although environmental racism/justice is a relatively small topic, it provides a window into the larger discipline. If race was more central, all human geographers would have a deeper understanding of it, which would, hopefully, be expressed in their research. I argue that the study of race has remained isolated within parts of geography because of disciplinary fragmentation, the limited number of people of color within the discipline, and our weak ties to ethnic studies.

Using a partially-autobiographical format, the first part of this essay traces my intellectual history and efforts to link Chicana/o Studies and environmental problems. Second, I consider geography's engagement with the study of race, and in particular, how the whiteness of the discipline has skewed our intellectual production. Using autobiography is not without its problems, however. Not only is it based on one person's experiences, but some may consider it self-indulgent. My hope, however, is that by revealing parts of my past we can gain a deeper understanding of how disciplinary cultures and practices, in addition to research, can have a significant affect on both scholars and scholarship.

\section{Becoming an Academic: Geography versus Chicana/o Studies}

Like many geographers, I stumbled onto the discipline. I took a California Geography course at the local community college and was immediately hooked. Geography, it seemed, provided answers to questions I was deeply curious about. For instance, growing up in southern California, I never understood why it didn't snow there. Equally perplexing was the apparent concentration of Blacks in south L.A., and Mexicans in east L.A. I decided that any discipline that could address both issues was for me.

Upon transferring to California State University Fresno, I majored in geography while participating in La Raza Studies. ${ }^{2}$ I took every environmentallyrelated course in the major, partly out of enthusiasm, and because that was what was offered. I simply accepted the divorce between my interests in Chicana/o Studies and Geography/Environmental issues - they were two separate worlds - and I had no idea how to integrate them. At the suggestion of one of my professors, I applied to the

${ }^{2}$ I should note that it was in a La Raza Studies course that I had my first Chicana instructor, Dr. Lea Ybarra. Because of her, I learned that it was possible for women like me to become academics. Politically, I am not a strong supporter of the "role model" strategy, but I must admit to the power of being shown the possibilities 
University of Wisconsin which offered a special fellowship for underrepresented minorities. $^{3}$

At Madison, I initiated my first attempt to combine my interests in Chicana/o Studies and Geography. My thesis examined farmworkers' experiences and perceptions with agricultural chemicals in the southern San Joaquin Valley. I somehow managed to complete my thesis, but was ultimately dissatisfied with the project. ${ }^{4}$ For one, I lacked the theoretical background to explain the structural vulnerability of farmworkers. In addition, having administered a survey, I was acutely aware of its inability to capture the complexity of exposure and the politics of environmental relationships. My advisors directed me to various literatures, including the work on urban hazards (Berry et al., 1977; Cutter, 1987; Johnson and Zeigler, 1986), as well as the political ecology literature (Hecht and Cockburn, 1989; Rocheleau, 1984; Watts, 1983). I was excited by the hazards research insofar as it was exploring urban inequalities, but I also found it theoretically unsatisfying, as it brought me no closer to understanding how race and racism worked. In contrast, I was drawn to political ecology, especially its oppositional nature, but I had enormous difficulties translating the inequalities of the "third world" to that of "domestic minorities". While I knew that race could only be understood in terms of larger power relations, I was not aware of any scholar who was making these connections within the human-environment tradition at the time - and I simply lacked the intellectual skills and maturity to make them myself. Of course, numerous geographers were studying race at the time, but most of it was in urban and social geography (Anderson, 1987; Jackson, 1987; Jackson and Smith, 1981; Peet, 1985), and operating within the human-environment tradition, I was not exposed to this work due to disciplinary fragmentation (see Hanson, 1999). This insularity is a major problem to which I will return.

An important part of my Madison experience was interacting with other Chicana/o graduate students. Ironically, both Chicano Studies and Geography were located in the same building. Though convenient, there was no programmatic or intellectual connection between the two units. This was even reflected in my social life: I had my geography friends (predominantly white), and my Chicana/o friends (not white). My Chicana/o colleagues were invaluable as we collectively faced the problem of how to integrate our interests in Chicana/o Studies with traditional disciplines that exhibited varying degrees of acceptance/hostility towards us and our work. Exacerbating the problem, of course, was the almost complete absence of any faculty of color. Through our association I began to see the problem in more structural terms. I

${ }^{3}$ I am grateful to Professor Jerry Towle for informing me about the Advanced Opportunity Fellowship, which still exists.

${ }^{4}$ I never would have completed my master's thesis without the tremendous support of my advisor, Diana Liverman, who continues to be a mentor. My dissatisfaction with the project in no way reflects on her, but on my own shortcomings. 
became critical of the University and geography, wondering why so few students of color were attracted to the discipline and its (and [my]) seeming inability to systematically address the connection between racism and environmental issues.

Things took a radical turn, however, as I began my Ph.D. in Urban Planning at UCLA. It was not that race was being seriously theorized there, but the department did take social justice seriously. Not only did I begin to study social theory, but there was a critical mass of students of color, including people like Clyde Woods, [who] provided a fertile ground for student activism, critiquing the white academy, and studying race. In addition, there was a dynamic Chicano Studies Research Center that I worked with. Besides being in an environment that supported me and my research interests, there was a simultaneous trend towards exploring the relationship between people of color and environmentalism. The United Church of Christ's study, Toxic Waste and Race in the United States, was published in 1987, and suddenly my research topic shifted from "minorities and the environment" to "environmental racism". working class Chicana/o environmentalism could not have happened at a more opportune time.

\section{Environmental Racism Research in Geography}

I was confident that environmental racism/justice would develop rapidly within the discipline. It is difficult to think of a more geographic topic, as it includes naturesociety relations, spatial analysis, and mapping. In addition, it encompasses different types of intellectual work, including empirical studies, policy-making, community activism, and theorizing. I believe that geography should have been the disciplinary home of environmental racism/justice, but instead, cognate disciplines, such as sociology, took the lead in exploring both environmental racism (racially unequal environmental quality) and environmental justice (the movement to counter environmental racism). ${ }^{6}$ I believe this was a lost opportunity - building a community of researchers around environmental racism/justice could have helped prioritized the study of race within geography.

This is not to diminish the important and diverse contributions geographers have made to the subject, including research on spatial distributions (Bowen, et al. 1995; Chakraborty and Armstrong, 2001; Cutter and Solecki, 1996), ethics and politics (Lake, 1996), land-use (Pincetl, 1996), community organizing (Berman Santana, 1996a), the environmental justice movement (Towers, 2000), and the political movement.

${ }^{5}$ The UCC report was the first national study of environmental racism and triggered a research

${ }^{6}$ This is an unfortunate development, because the "nature" side of the equation often gets ignored by sociologists. 
economy of hazards (Heiman, 1990). Missing from this impressive body of literature, however, is a systematic focus on race, which to me, is a core concept of environmental racism (Berman Santana, 1996b; Pulido, 2000, 1996). Regardless of motive, it is difficult to avoid the conclusion that geographers studying this topic have shown a clear preference for not tackling directly the question of race and racism.

Though researchers have explored racial disparities in the location of hazards and pollution, geography's insights on race exceed that of spatial analysis. If we understand race to be an ideological and material process, it should be apparent that it is a fundamentally spatial relation. Consequently, geography should be a leading discipline in the study of race. But it is not.

\section{Geography, Geographers, and the Study of Race}

Despite historical obstacles to the study of race within geography, including the discipline's role in imperialism (Smith and Godlewska, 1994) and environmental determinism (Peet, 1985), geographers have contributed a great deal to the study of racial inequality (for excellent overviews, see Kodras, no date; Dwyer, 1997). ${ }^{7}$ There are many ways to analyze this large body of work, but one important distinction is between those studies that document racial differences and more recent work grounded in critical race theory. Both are valuable in their own right. The first body of literature, often adhering to a more positivist approach, is particularly significant in terms of policy. Such research findings can actually be used in political, administrative, and legal decisions. The second category, critical race theory, is less policy-oriented, but has important implications for how we think about race. One of its most important characteristics is that it does not treat racism as an aberration, but assumes that race is a fundamental social relation. In contrast, while studies that seek to document racial outcomes may or may not view race as an aberration, they allow racism to be treated that way. This is a key issue: if racism is inherent to a social formation, then it is difficult to segregate it, either as a topic or in one's analysis. This is not the case with methodological approaches that acknowledge the existence of racism only if the findings support such a conclusion. It is not my intent to disparage either approach, but rather to call attention to this fundamental divide and encourage geographers to begin crossing this boundary. It is my contention that at present these two sets of researchers are largely talking past each other, when instead we should be engaging each other. Critical race theorists should be encouraged to make direct contributions to policy, legal, and activist arenas, whereas those documenting racial outcomes would benefit

${ }^{7}$ It is important to differentiate between scholarship on nonwhites and the study of race itself. The two are clearly distinct, but studies on people of color, particularly African Americans, often serve as a segue to the study of race, and unfortunately, sometimes as a substitute. 
from asking what race is and trying to understand it in all of its complexities. Until we reach this point, geography's work on race will remain fragmented and weak.

Of course, geography is not so different from the larger society. While there is a distinct minority that insists on the reality of racism, there has been a dramatic shift in racial attitudes. Though there is no denying that many forms of overt racism have decreased, large percentages of the population, particularly whites, no longer support integration efforts and anti-racist initiatives (Edsall and Edsall, 1991), as seen in the demise of affirmative action in California. We need to appreciate that geographers are just people and in many ways reflect the experiences and dynamics of the larger population, particularly the white one.

This brings us to another reason for the marginalization of the study of race within geography: the overwhelming white composition of the discipline and its limited links to ethnic studies. While I must tread carefully here if I wish to avoid essentialist arguments, I believe there is no escaping the fact that in a discipline that is over 90\% white (Association of American Geographers, 1999), many individuals feel no need or desire to investigate race, as the current racial hierarchy serves them well. Simply put, race is not a problem for most geographers in their daily lives. ${ }^{8}$ This individual preference for not studying race is magnified by several thousand and has become a characteristic of the discipline. Conversely, I believe that more people of color would contribute to a more robust and dynamic dialogue on race within geography. Unlike whites, the racial formation does not benefit people of color to the same extent. Depending upon one's racial/ethnic identity, economic position, gender, sexuality, ability, and location, people of color occupy various positions of racial subordination. As a result, race is a "problem" that needs to be studied. Clearly, there are a number of white geographers who have consciously stepped outside this position, but they remain a minority. And even committed white scholars must contend with numerous obstacles in the study of race, including issues of representation and the politics of fieldwork. Not only must white researchers deal with the political and ethical issues associated with whites studying racially-subordinated populations, but there is also the problem of whites telling, once again, the stories of people of color and the subject even sometimes speaking back. These tensions might partially account for the intense popularity of whiteness studies. In addition to the admittedly important task of unpacking hegemonic racial groups and practices, it may be that whiteness is just a less problematic area of inquiry (Bonnet, 1998, 1997; Dyer, 1988; Frankenberg, 1993; Ignatiev, 1995; Jackson, 1998; Lipsitz, 1998; Roediger, 1991; for a fuller discussion of these issues see Kobayashi and Peake, 2000; Mahtani, 2001; McGuiness, 2000; Rodriguez, 1999).

${ }^{8}$ There are, in fact, many ways in which we all suffer from racial inequality. However, geography, for the most part, is still trying to understand how racially-subordinated populations differ from that of the white majority. Hopefully, we can have a conversation on the collective material, social, emotional, and spiritual costs of racism one day. 


\section{The Whiteness of Geography and Intellectual Production}

Certainly there is recognition that geography, ideally, should become more diverse. It has been suggested that diversification would facilitate outreach, make geography more relevant to otherwise underserved communities, and that it is simply the "right" thing to do, both morally and politically (Janelle, 1992, 380-83; Rediscovering Geography Committee, 1997, 154-55; Shrestha and Davis, 1989). What has not been argued, however, is how the whiteness of our discipline skews our intellectual production (see Zelinksy, et al. $\{1982\}$, and Rose $\{1993\}$ for a similar argument in terms of gender).

I am not implying that white geographers are incapable of producing cuttingedge work on race, or that scholars of color are more likely to have more penetrating insights and analyses. On the contrary, white geographers, have produced exceptional work (some recent works include, Allen and Turner, 1997; Anderson, 1987; Blaut, 1993; Clark and Rose, 1994; Delaney, 1998; Dwyer, 1999; Elder, 1998; Gilbert, 1998; Jackson and Penrose, 1994; Nast, 2000; Pratt and Hanson, 1994; Twine, 1996; Tyner and Houston, 2000; Wilson, 1996. For a complete review, see Kodras, no date), as have geographers of color (Berman Santana, 1996a,b; de Oliver, 1996; Gilmore, 1999; Kobayashi and Peake, 1994; Wilson, 2000, 1992; Woods, 1998). Nonetheless, more geographers of color would enhance our disciplinary discourse on race in several ways. First, more people of color could create a "critical mass", which currently does not exist. Derald Smith (1993, 255) defines critical mass as "the necessary number of persons to generate original major ideas of a regional, global or scientific breakthrough scale...". In this case, we need sufficient scholars to generate an intellectual synergy around race. A similar process can be seen in feminist geography. Only after women gained access to academia did the study of gender flourish. Men could have taken the lead, but they did not. Because patriarchy was a problem for female geographers, they studied it seriously. While most early works were corrective in nature (McDowell, 1993), feminist geography has since become one of the most vibrant sites of human geography.

Evidence has shown that within nonwhite intellectual spaces, race consistently emerges as a key interest. One need only look at the conference proceedings of the National Association of Chicano Studies, the Association of Asian American Studies, the countless African American Studies organizations, or even the Latino Caucus of the American Sociology Association, to see that race, both as a reality informing people's everyday lives, and as a dynamic area of intellectual engagement, are major themes. Certainly not all people of color will or should be interested in exploring these topics, but were there more geographers of color, I am confident that some of them 
would. As few as fifteen people could constitute a critical mass and their energy could have a major impact on how the discipline addresses race in all its forms. ${ }^{9}$

Another, often overlooked dimension of a white discipline is the limited set of experiences that inform the discourse. As previously explained, we all occupy different racial positions and experience race differently. While I will argue strenuously that race is a rigorous area of scholarship, there is no denying that we all have experiences and feelings about race, since we are all racialized. Studies suggest that racial thinking pervades our mind, and consequently, these experiences inform our research, consciously or not (Devine, 1989; Lawrence, 1987). Currently, geography is unduly informed by experiences of whiteness. This does not mean that whites cannot empathize, research, or stand in solidarity with those who are racially subordinated, but it does mean that the voices and experiences of nonwhites are almost always filtered through a white lens. Undoubtedly, the literature would be enhanced by a wide-range of experiences.

Finally, more people of color would enhance geography by offering closer ties to ethnic studies. Because it is scholars of color who tend to belong to racial/ethnic scholarly associations (how many white geographers belong to the National Association of Chicano Studies?), we become, in effect, the bridges between geography and ethnic studies, where some of the most pathbreaking work on race is taking place (Kondo, 1997; Lipsitz, 1998; Lowe, 1996; Sanchez, 1993). Geography might do well to emulate American Studies which has flourished partly by reaching out to ethnic studies. Traditionally associated with "colonial" studies (i.e. unreconstructed white studies), the Association made a conscious decision to integrate itself and to reach out to the scholarly associations of various racial/ethnic groups (Lipsitz, 1995; Washington, 1998). This has led to an impressive, but still incomplete, integration of the discipline. Moreover, it has contributed to a reinvigoration of the study of race which is reverberating throughout academia. There is no reason geography should not be part of this.

\section{Towards a New Disciplinary Culture}

I have tried to identify several reasons why the study of race is both marginalized and fragmented within geography. In addition to disciplinary and institutional barriers to methodological boundary-crossing, I believe that the paltry number of geographers of color is a factor. In contrast, if geography had more people of color, for whom race is often a problematic experience, then perhaps the discipline's racial discourse would be enriched. While I don't have any magic solution to promote

${ }^{9}$ Although it is too early to tell, it is possible that the Kentucky gathering might serve as the beginning of such a critical mass. 
the diversification of the discipline, I do know, based on my own experience, what some faculty of color are drawn to. I recently changed my appointment at USC from full-time in geography to half-time in the Program in American Studies and Ethnicity (PASE) ${ }^{10}$ PASE is a relatively new interdisciplinary program that includes within it Chicano/Latino, African American, and Asian American Studies. While some have been disappointed with my lack of disciplinary loyalty, the intellectual community and overall feeling of comfort associated with PASE were simply too compelling to pass up. Obviously, the actions of a single individual are not necessarily significant, but this latest move might once again be instructive in highlighting what attracts at least some faculty of color.

\section{Comfort}

Few whites will ever appreciate the enormous psychological and emotional energy that many people of color expend when in all white environments. This doesn't mean that we are incapable of caring for or being friends with white colleagues, but I have had enough conversations with geographers of color to know that being a "minority" is enormously draining. I, for one, am much more relaxed and able to be myself in situations that are either racially-mixed or predominantly people of color. This may seem like whining or insignificant to some, but the daily challenge of facing predominantly white students and colleagues does take its toll. In the past, scholars of color may have just accepted this as reality, but I think that the number of women and people of color shifting into either women's studies or ethnic studies, is indicative of a discipline in dire need of change.

\section{Intellectual Community}

A second reason for my change of appointment was that it offered me a much more stimulating set of intellectual opportunities in which to deepen my understanding of race. While my PASE colleagues may not be very good at mapping and sometimes reduce spatial analysis to metaphors, they bring a wealth of experience and expertise regarding one of the key problems facing the world today: racial inequality. As a result, I enjoy a more diverse and interdisciplinary set of opportunities that are meaningful to me. Previously, I sometimes felt pressure to emphasize the geographic dimensions of race, instead of being free to study it for its own sake.

${ }^{10}$ This should not be read as an indictment of the Department of Geography at USC, which has offered above average support. I was not so much "pushed" as "pulled" to PASE, because it offered things that geography simply could not. 
Although there were other issues, comfort and intellectual community were the key reasons I made the move. It is entirely possible that these are just my own personal idiosyncrasies, but I think not, given the large and highly-talented pool of faculty of color that PASE has been able to attract. What does this mean for geography? In addition to such things as student recruitment, mentoring, and funding, we need to change the very culture of our discipline. Although this will inevitably be a multipronged project, any serious strategy must include efforts to make geography more comfortable for people of color (and others), and encourage opportunities for innovative forms of intellectual community. Maybe instead of people of color having to assimilate to the white culture(s) of academia, it's time for academia to accommodate us.

\section{Literature Cited}

Allen, J. and E. Turner. 1997. The Ethnic Quilt: Population Diversity in Southern California. Northridge: Center for Geographical Studies, California State University Northridge.

Association of American Geographers. 1999. Profiles of the AAG Membership 19961998. Newsletter of the American Association of Geographers 34(5), 20.

Anderson, K. 1987. The idea of Chinatown: The power of place and institutional practice in the making of a racial category. Annals of the Association of American Geographers 77, 580-98.

Berman Santana, D. 1996a. Kicking Off the Bootstraps: Environment, Development and Community Power in Puerto Rico. Tuscon: University of Arizona Press.

Berman Santana, D. 1996b. Geographers, colonialism, and development strategies: The case of Puerto Rico. Urban Geography 17(5), 456-74.

Berry, B. (ed). 1977. The Social Burdens of Environmental Pollution: A Comparative Metropolitan Data Source. Cambridge, MA: Ballinger Publications.

Blaut, J. 1993. The Colonizer's Model of the World. New York: Guilford.

Blaut, J. 1992. The theory of cultural racism. Antipode 24(4), 289-99.

Bonnett, A. 1998. How the British working class became white: The symbolic (re)formation of racialized capitalism. Journal of Historical Sociology 11 (3), $316-40$.

Bonnett, A. 1997. Geography, 'race', and whiteness: Invisible traditions and current challenges. Area 29(3), 193-99. 
Bowen, W., M. Salling and E. Cyran. 1995. Toward environmental justice: Spatial equity in Ohio and Cleveland. Annals of the Association of American Geographers 85(4), 641-63.

Chakraborty, J. and M. Armstrong. 2001. Assessing the impact of airborne toxic releases on populations with special needs. Professional Geographer 53(1), 11931 .

Cutter, S. 1987. Airborne toxic releases: Are communities prepared? Environment 29 (6), 12-17, 28-31.

Cutter, S. and W. Solecki. 1996. Setting environmental justice in space and place: Acute and chronic airborne toxic releases in the Southeastern U.S. Urban Geography 17(5), 380-99.

Cutter, S. and M. Tiefenbacher. 1991. Chemical hazards in urban America. Urban Geography 12 (5), 417-30.

De Oliver, M. 1996. Historical preservation and identity: The Alamo and the production of a consumer landscape. Antipode 28(1), 1-23.

Delaney, D. 1998. Race, Place and the Law, 1836-1948. Austin: University of Texas Press.

Devine, P. 1989. Stereotypes and prejudice: Their automatic and controlled components. Personality and Social Psychology 56(1), 5-18.

Dwyer, O. 1999. Interpreting the Civil Rights Movement: Place, Memory and Conflict. Unpublished manuscript. Department of Geography, University of Kentucky.

Dwyer, O. 1997. Geographical research about African Americans: A survey of journals, 1911-1995. The Professional Geographer 49 (4), 441-51.

Dyer, R. 1988. White. Screen 29(4), 44-64.

Elder, G. 1998. The South African body politic: Space, race, and heterosexuality. In, H. Nast \& S. Pile (eds.), Places through the Body. New York: Routledge, pp. $153-64$.

Edsall, T. and M. Edsall. 1991. Chain Reaction. New York: W.W. Norton.

Frankenberg, R. 1993. White Women, Race Matters: The Social Construction of Whiteness. Minneapolis: University of Minnesota.

Gilbert, M. 1998. "Race", Space and power: The survival strategies of working poor women. Annals of the Association of American Geographers 88(4), 595-621. 
Gilmore, R. W. 1991. You have dislodged a boulder: Mothers and prisoners in the post-Keynsian California landscape. Transforming Anthropology 8(1 \& 2), 13344.

Hanson, S. 1999. Isms and schisms: Healing the rift between the nature-society and space-society traditions in Human Geography. Annals of the Association of American Geographers 89(1), 133-44.

Hecht, S.B. and A. Cockburn. 1989. The Fate of the Forest: Developers, Destroyers and Defenders of the Amazon. London; New York: Verso.

Heiman, M. 1990. From 'Not in My Backyard!' to 'Not in Anybody's Backyard!': Grassroots challenges to hazardous waste facility siting. American Planning Association Journal 56, 359-62.

Ignatiev, N. 1995. How the Irish Became White. New York: Routledge.

Jackson, P. 1998. Constructions of 'whiteness' in the geographical imagination. Area 30(2), 99-106.

Jackson, P. (ed). 1987. Race and Racism: Essays in Social Geography. London; Boston: Allen and Unwin.

Jackson, P. and J. Penrose (eds). 1994. Constructions of Race, Place and Nation. Minneapolis: University of Minnesota Press.

Jackson, P. and S. J. Smith. 1981. Social Interaction and Ethnic Segregation. London; New York: Academic Press.

Janelle, D. 1992. The peopling of American geography. In, R. Abler, M. Marcus \& J. Olson (eds.), Geography's Inner Worlds. New Brunswick: Rutgers University Press, pp. 363-90.

Johnson, J. and D. Zeigler. 1986. Evacuation planning for technological hazards: An emerging imperative. Cities 3, 148-56.

Johnson, J. and M. Oliver. 1991. Economic restructuring and black male joblessness in U.S. Metropolitan Areas. Urban Geography 12(6), 542-62.

Kobayashi, A. and L. Peake. 2000. Racism out of place: Thoughts on whiteness and an antiracist geography in the new millennium. Annals of the Association of American Geographers 90(2), 392-403.

Kobayashi, A. and L. Peake. 1994. Unnatural discourse: 'Race' and gender in geography. Gender, Place and Culture 1, 225-44. 
Kodras, J. nd. Race and Place: Geographic Research on Race Relations in the United States. Unpublished manuscript. Department of Geography, Florida State University.

Kondo, D. 1997. About Face: Performing Race in Fashion and Theater. New York and London: Routledge.

Lake, R. 1996. Volunteers, NIMBYs and environmental justice: Dilemmas of democratic practice. Antipode 28(2), 142-59.

Lake, R. 1980. Racial transition and black homeownership in American suburbs. Annals of the American Academy of Political and Social Science 441, 142-56.

Lawrence, C. 1987. The Id, the Ego and equal protection: Reckoning with unconscious racism. Stanford Law Review 39, 317-88.

Lipsitz, G. 1998. The Possessive Investment in Whiteness. Philadelphia: Temple University Press.

Lipsitz, G. 1995. The possessive investment in whiteness: Racialized social democracy and the 'white' problem in American studies. American Quarterly 47(3), 369-87.

Liverman, D. 1999. Geography and the global environment. Annals of the Association of American Geographers 89(1), 107-20.

Lowe, L. 1996. Immigrant Acts: On Asian American Cultural Politics. Durham: Duke University Press.

Mahtani, M. 2001. Racial re-mappings: The potential of paradoxical space. Gender, Place \& Culture 8(3), 299-305.

McDowell, L. 1993. Space, place, and gender relations: Part I - Feminist empiricism and the geography of social relations. Progress in Human Geography 17(2), 15779.

McGuinness, M. 2000. Geography matters? Whiteness and contemporary geography. Area 32(2), 225-30.

Moss, P. (ed.) Placing Autobiography in Geography. Syracuse: Syracuse University Press.

Nast, H. 2000. Mapping the unconscious. Annals of the Association of American Geographers 90(2), 215-55.

Peet, R. 1985. The social origins of environmental determinism. Annals of the American Association of Geographers 75(3), 309-33. 
Pincetl, S. 1996. Immigrants and redevelopment plans in Paris, France: Urban planning, equity, and environmental justice. Urban Geography 17(5), 440-55.

Pratt, G. and S. Hanson. 1994. Geography and the construction of difference. Gender, Place and Culture 1(1), 5-29.

Pulido, L. 2000. Rethinking environmental racism: White privilege and urban development in Southern California. Annals of the Association of American Geographers 90(1), 12-40.

Pulido, L. 1996. A critical review of the methodology of environmental racism research. Antipode 28(2), 142-49.

Rediscovering Geography Committee. 1997. Rediscovering Geography: New Relevance for Science and Study. Washington, D.C.: National Academy Press.

Rocheleau, D. 1984. An Ecological Analysis of Soil and Water Conservation in Hillslope

Farming Systems: Plan Sierra, Dominican Republic. Ph.D dissertation, University of Florida.

Rodriguez, R. 1999. The study of whiteness. Black Issues in Higher Education 16(6), $20-5$.

Roediger, D. 1991. The Wages of Whiteness. New York: Verso.

Rose, G. 1993. Feminism and Geography. Minneapolis: University of Minnesota Press.

Sanchez, G. J. 1993. Becoming Mexican American: Ethnicity, Culture and Identity in Chicano Los Angeles, 1900-1945. New York: Oxford University Press.

Shrestha, N. and D. Davis. 1989. Minorities in geography: Some disturbing facts and policy measures. The Professional Geographer 41(4), 410-20.

Smith, D. 1993. Fluvial geomorphology: Where do we go from here? Geomorphology 7, 251-62.

Smith, S. 1993. Residential segregation and the politics of racialization. In, M. Cross \& M. Keith (eds.), Racism, the City and the State. New York: Routledge, pp. 12843.

Smith, N. and A. Godlewska (eds). 1994. Geography and Empire. Cambridge: Blackwell. 
Towers, G. 2000. Applying the political geography of scale: Grassroots strategies and environmental justice. Professional Geographer 52(1), 23-36.

Twine, F. W. 1996. Brown skinned girls: Class, culture and the construction of white identity in suburban communities. Gender, Place, and Culture 3(2), 205-24.

Tyner, J. and D. Houston. 2000. Controlling bodies: The punishment of multiracializaed sexual relations. Antipode 32(4), 387-409.

United Church of Christ, Commission on Racial Justice. 1987. Toxic Wastes and Race in the United States. New York: United Church of Christ.

Washington, M. H. 1998. Disturbing the peace: What happens to American Studies if you put African American Studies at the center? Presidential address to the American Studies Association, October 29, 1997. American Quarterly 50(1), 123.

Watts, M. 1983. Silent Violence: Food, Famine and Peasantry in Northern Nigeria. Berkeley: University of California Press.

Wilson, B. 2000. Race and Place in Birmingham. Lanham, MD: Rowman \& Littlefield.

Wilson, B. 1992. Structural imperatives behind racial change in Birmingham, Alabama. Antipode 24, 171-202.

Wilson, D. 1996. Metaphors, growth coalition discourses, and black poverty neighborhoods in a U.S. City. Antipode 28(1), 72-96.

Woods, C. 1998. Arrested Development: Regional Planning in the Mississippi Delta. New York: Verso.

Zelinsky, W., J. Monk and S. Hanson. 1982. Women and geography: A review and prospectus. Progress in Human Geography 6, 317-66. 